\title{
$\mathrm{PVdF}$ 계 미세기공 고분자 전해질의 전기화학적 특성
}

\author{
정강국 · 김종욱* - 안주현 ${ }^{\dagger}$ 김기원** - 안효준** \\ 경상대학교 화학공학과 및 $\mathrm{IT}$ 용 에너지 저장 및 변환센터 \\ *경상대학교 IT용 에너지 저장 및 변환센터 \\ **경상대학교 금속재료공학과 및 IT용 에너지 저장 및 변환센터 \\ (2004년 9월 1일 접수 : 2004년 9월 17일 채택)
}

\section{Electrochemical Characteristics of Microporous Polymer Electrolytes Based on Poly(vinylidene-co-hexafluoropropylene)}

\author{
Kang-Kook Jung, Jong-Uk Kim*, Jou-Hyeon $\mathrm{Ahn}^{\dagger}$, Ki-Won Kim**, and Hyo-Jun Ahn** \\ Department of Chemical Engineering and ITRCESC, Gyeongsang National University, Jinju 660-701, Korea \\ *ITRC for Energy Storage \& Conversion, Gyeongsang National University, Jinju 660-701, Korea \\ **Department of Metallurgical and Materials Engineering and ITRCESC, Gyeongsang National University, Jinju 660-701, Korea
}

(Received September 1, 2004 : Accepted September 17, 2004)

\begin{abstract}
초록
리튬 설퍼전지용 고분자 전해질을 개발하기 위해 상전이 방법으로 미세기공 $\mathrm{P}(\mathrm{VdF}-\mathrm{HFP})$ 고분자 필름을 제조하였다. 미세기공 고분자 전해질은 $\mathrm{NMP}$ 추출에 사용되는 증류수와 메탄올의 혼합 농도를 조절함으로써 고분자 필름 내부의 기공 구조 형성을 제어할 수 있었다. $80 \%$ 메탄올로 제조한 미세기공 고분자 필름에 $1 \mathrm{M} \mathrm{LiCF}_{3} \mathrm{SO}_{3}$-TEGDME/EC의 액체 전해질을 함침시켜 제조한 고분자 전해질이 가장 높은 이온 전도도를 나타냈으며 리틈 이차전지에 사용 가능한 $2 \times 10^{-3} \mathrm{~S} / \mathrm{cm}$ 의 이온전도도를 나타내었다. 또한 고분자 필름의 기공도가 균일하고 저장 시간에 따른 이온전도도 감소도 적었으며, 리튬 전극과의 계면저항도 가장 낮게 나타났다. 리튬염에 따른 이온전도도를 측정한 결과 $\mathrm{LiPF}_{6}$ 를 사용한 고분자 전해질이 상온에서 $3.3 \times 10^{-3} \mathrm{~S} / \mathrm{cm}$ 로 나타났다.
\end{abstract}

\begin{abstract}
In order to develop polymer electrolyte for lithium/sulfur batteries, highly microporous P(VdF-HFP) membranes were prepared by phase inversion method. Porous structure was controlled by extracting NMP with mixture of deionized water and methanol. Porous structure of the membranes was observed with SEM. Polymer electrolytes were prepared by soaking the porous membranes in $1 \mathrm{M} \mathrm{LiCF}_{3} \mathrm{SO}_{3}$-TEGDME/EC. The ionic conductivity of polymer electrolyte was found to be as high as $2 \times 10^{-3} \mathrm{~S} / \mathrm{cm}$ when the polymer membrane extracted by $80 \%$ methanol was used. The microporous polymer electrolyte optimized in this work displayed high ionic conductivity, uniform pore size, low interfacial resistance and stable ionic conductivity with storage time. The ionic conductivity of polymer electrolytes was measured with various lithium salts, and the conductivity showed $3.3 \times 10^{-3} \mathrm{~S} / \mathrm{cm}$ at room temperature when $\mathrm{LiPF}_{6}$ was used as a lithium salt.
\end{abstract}

Key words : Microporous membrane, Polymer electrolyte, Ionic conductivity, Lithium sulfur battery.

\section{1. 서 론}

고분자 전해질에 대한 연구는 알칼리 금속염을 포함하는 poly(ethylene oxide)(PEO)가 이온전도도를 갖는다고 보고한 Wright 등의 연구로부터 시작되었다. ${ }^{1)}$ 이와 같은 고분자 전해 질은 $60^{\circ} \mathrm{C}$ 이상의 고온에서는 $10^{-4} \mathrm{~S} / \mathrm{cm}$ 의 비교적 높은 이온전 도도를 나타내지만, 상온에서는 $10^{-8} \mathrm{~S} / \mathrm{cm}$ 정도의 매우 낮은 이 온전도도롤 나타넨다. 고분자 전해질의 이온전도도를 향상시키

${ }^{\dagger}$ E-mail: jhahn@gsnu.ac.kr
기 위하여 지금까지 많은 연구들이 수행되어 왔다. ${ }^{2.3)}$ 1990년 이후 상업적으로 사용 가능한 $10^{-3} \mathrm{~S} / \mathrm{cm}$ 이상의 이온 전도도를 가진 겔 고분자 전해질의 연구가 횔발히 이루어지고 있다. 겔 고분자 전해질은 고분자 매트릭스에 가소제의 역할로 액체 전해질을 넣어 제조한다. 액체 전해질의 함유로 이온의 이 동도가 증가하여 이온전도도가 아주 높게 나타난다. 이러한 겔 고분자 전해질의 매트릭스로 사용되는 고분자로는 PEO, Polyacrylonitrile(PAN), Poly(methyl methacrylate)(PMMA), Poly (vinylidene fluoride)(PVDF) 등이 있다. ${ }^{4-12)}$ 이러한 고분자들 중 PVdF계열의 Poly(vinylidene fluoride-co-hexafluoropropylene) 
(PVdF-HFP)가 기계적 강도와 안정성이 촣아 겔 고분자 전해질 의 매트릭스용 고분자로 많이 연구되고 있다. . $^{3-15)}$

액체 전해질을 가소제로 사용한 겔 고분자 전해질은 높은 이 온 전도도를 나타내기는 하지만 수분과의 반응성 때문에 고분 자 전해질의 제조공정이 글로브박스 내에서 모두 수행되어져야 한다. 또한 가소제로 사용된 액체 전해질이 고분자 전해질로부 터 서서히 상분리 되어지며, 기계적 강도가 좋지 않아 취급하기 에 어려움이 있다. Bellcore사에서 대기 중에서 미세기공 고분 자 필름(microporous polymer film)을 제조한 후 글로브박스 내에서 이 필름에 액체 전해질을 함침시킨 고분자 전해질을 제 조하는 방법을 발표하였다. ${ }^{16)}$ 이 방법은 기공 형성을 위해 din-butyl phthalate(DBP)와 같은 가소제를 $\mathrm{PVdF}$ 가 녹아있는 아 세톤 용액에 첨가한 후 이 용액을 유리판 위에 캐스팅(casting) 하여 아세톤을 휘발시키면 $\mathrm{PVdF}$ 와 $\mathrm{DBP}$ 가 상분리된 고분자 필 름을 얻는다. PVdF에는 비용매인 에테르 또는 메탄올로 DBP 를 추출하여 미세기공 고분자 필름을 제조한다. 이 방법으로 제 조된 고분자 전해질은 기존의 겔 고분자 전해질과 이온전도도 는 비슷하나, 우수한 기계적 강도를 나타내었다. 무엇보다도 대 기 중에서 고분자 필름을 제조하기 때문에 제조방법이 매우 용 이하다는 장점이 있다. 또한 가소제를 넣지 않고 고분자가 녹아 있는 용액을 캐스팅하고 고분자에 대한 비용매를 사용하여 미 세기공 고분자 필름을 제조하는 상전이 방법(phase inversion method) ${ }^{17-20) ㄷ ㅗ ~ ㄴ ㅓ ㄹ ㄹ ㅣ ~ ㅅ ㅏ ㅇ ㅛ ㅇ ㄷ ㅚ ㅁ ㅕ, ~ ㅇ ㅣ ㄹ ㅓ ㅎ ㅏ ㄴ ~ ㄱ ㅕ ㅇ ㅇ ㅜ ~ ㅋ ㅐ ㅅ ㅡ ㅌ ㅣ ㅇ ㅎ ㅏ ㄱ ㅣ ㅇ ㅔ ~ ㅈ ㅓ ㄱ ㅈ ㅓ ㄹ ~}$ 한 점도를 지닌 고분자용액을 제조하는 것이 매우 중요하다.

본 연구에서는 리튬 이차전지용 고분자 전해질을 개발하기 위 해 고분자 매트릭스로 P(VdF-HFP), 용매로 N-methylpyrrolidone(NMP)를 사용하여 고분자 용액을 혼합하고 캐스팅 한 후 비용매로 증류수, 증류수-메탄올 및 $100 \%$ 메탄올 등을 이 용하여 NMP를 추출하는 상전이 방법으로 미세기공 고분자 필 름을 제조하고, 여기에 리튬염과 액체 전해질을 함침시켜 고분 자 전해질을 제조하였다. 제조한 고분자 전해질의 이온전도도, 임피던스 특성, 전기화학적 안정성 및 열적 안정성 등을 조사하 여 미세기공 고분자 전해질의 리튬 이차전지용 응용 가능성을 연구하였다.

\section{2. 실 험}

\section{1. 미세기공 고분자 필름 제조}

고분자 매트릭스인 P(VdF-HFP)(Kynar Flex 2801, Elf Atochem.)를 NMP에 1:5의 무게비로 혼합하여 적절한 점도를 지닌 고분자 용액을 제조하였다. $60^{\circ} \mathrm{C}$ 에서 24 시간 동안 교반하 여 균일하게 혼합한 후, 고분자 용액을 유리판 위에 일정한 두 께로 캐스팅하여 증류수, 중류수-메탄올 혼합물 및 메탄올로 $\mathrm{NMP}$ 를 추출하여 미세기공 고분자 필름을 제조하였다. NMP 추 출시 고분자 필름의 표면이 반투명한 고체로 상전이가 일어나 면서 거칠어지고 필름의 수축이 일어나는 것을 방지하기 위해 글래스로 압착시켜 NMP를 추출하였다. 사용한 비용매로 여러 차례 세척하여 남아있는 NMP를 완전히 제거하였다. NMP 추 출 후 상온에서 건조한 후 $60^{\circ} \mathrm{C}$ 에서 24 시간 진공 건조시켜 고 분자 필름내에 잔존하는 비용매를 완전히 제거하였다.

\section{2. 미세기공 고분자 전해질의 제조}

리튬염을 포함하는 액체 전해질을 미세기공 고분자 필름에 함 침시켜 고분자 전해질을 제조하였다. 사용한 리튬염은 lithium triflate( $\left(\mathrm{LiCF}_{3} \mathrm{SO}_{3}\right.$, Aldrich), lithium borate $\left(\mathrm{LiBF}_{4}\right.$, Aldrich), lithium phosphate $\left(\mathrm{LiPF}_{6}\right.$, Aldrich)이었으며, $1 \mathrm{M}$ 의 리튬염에 액 체 전해질의 용매로 사용하는 tetraethylene glycol dimethyl ether(TEGDME, Aldrich), ethylene carbonate(EC, 제일모직), propylene carbonate (PC, Aldrich) 및 dimethyl carbonate (DMC, Aldrich) 등을 1:1의 체적비로 섞은 혼합 용액을 사용 하여, 상온에서 1 시간 동안 고분자 필름을 액체 전해질에 함침 시켜 사용하였다. 모든 제조과정은 아르곤 분위기의 글로브박스 내에서 행하였다.

\section{3. 특성 조사}

미세기공 고분자 필름의 표면 및 벌크(bulk)의 구조롤 scanning electron microscope(SEM, JEOL 5600)를 이용하여 조사하였다. 미세기공 고분자 필름 및 액체 전해질을 함유한 고 분자 전해질의 열적 특성은 differential scanning calorimeter (DSC, TA Instrument)를 이용하여 조사하였다. 시료는 알루미 납 crimp pan속에 넣고, $30 \sim 200^{\circ} \mathrm{C}$ 까지 온도범위를 $5^{\circ} \mathrm{C} / \mathrm{min}$ 의 주사속도로 실시하였다.

미세기공 고분자 전해질의 이온전도도는 stainless steel 재질 의 Swagelok cell을 이용하여 $10 \mathrm{~Hz} 100 \mathrm{kHz}$ 의 주파수 범위 로 $\mathrm{AC}$ 임피던스를 측정하여 구하였으며, 미세기공 고분자 전해 질과 리튬과의 계면저항을 측정하기 위해 고분자 전해질과 $\mathbf{L i}$ 전극을 사용한 non-blocking electrode cell을 구성하여 0.1 $\mathrm{Hz} 100 \mathrm{kHz}$ 의 주파수 범위에서 $\mathrm{AC}$ 임피던스를 측정하였다. 또 한 linear sweep voltammetry(LSV)를 측정하여 미세기공 고분 자 전해질의 분해전압을 조사하였다.

\section{3. 결과 및 고찰}

미세기공 고분자 필름을 제조하기 위하여 $\mathrm{P}(\mathrm{VdF}-\mathrm{HFP})$ 를 용 매인 NMP에 녹여 유리판 위에 캐스팅한 후 $\mathrm{P}(\mathrm{VdF}-\mathrm{HFP})$ 에 대 해 비용매인 증류수, 메탄올 및 증류수-메탄올 혼합액 동으로 $\mathrm{NMP}$ 를 추출하는 상전이 방법을 이용하였다. 비용매로는 용매 인 NMP와는 잘 섞이면서 고분자인 $\mathrm{P}(\mathrm{VdF}-\mathrm{HFP})$ 를 녹이지 않 는 것을 선택하여야 한다. 이 경우에 미세기공 고분자 필름의 기공 형태와 크기가 비용매와 고분자간의 친화력에 따라 달라 질 수 있다. 비용매로는 증류수, $20 \%$ 메탄올, $40 \%$ 메탄올, $60 \%$ 메탄올, $80 \%$ 메탄올 및 순수 메탄올이 사용되었으며, 제 조한 고분자 필름의 표면과 내부구조를 $\mathrm{SEM}$ 으로 관찰하여 그 결과를 Fig. 1과 Fig. 2에 나타내었다. Fig. 1에서 보는 바와 같이 $\mathrm{P}(\mathrm{VdF}-\mathrm{HFP})$ 고분자 필름의 표면은 전체적으로 기공(pore) 들이 잘 발달되어 있는 것을 관찰할 수 있었으며, 증류수를 사 용하여 NMP를 추출하였을 경우 기공 크기가 가장 크게 발달 하였고, 메탄올의 비율이 증가할수록 기공 크기가 작아지는 것 을 알 수 있었다. 또한 순수 메탄올을 비용매로 사용하여 NMP 를 추출한 경우 $\mathrm{P}(\mathrm{VdF}-\mathrm{HFP})$ 가 클러스터를 형성하고 그 사이에 기공들이 형성되었으나 다른 것과 비교하여 기공이 거의 발달 되지 않음을 알 수 있었다.

Fig. 2는 다양한 종류의 비용매를 이용하여 제조한 고분자 필 름의 내부구조를 $\mathrm{SEM}$ 으로 관찰한 것이다. 기공들이 필름 내부 에 상당히 잘 발달되어 있는 것을 관찰할 수 있었으며, 증류수 를 비용매로 사용하여 NMP를 추출한 고분자 필름은 $50 \mu \mathrm{m}$ 이 상의 동굴형태의 기공이 발달되어 있고 그 주변에 $2 \sim 3 \mu \mathrm{m}$ 의 작은 기공이 형성되었다. 비용매로 사용한 메탄올 농도가 증가 


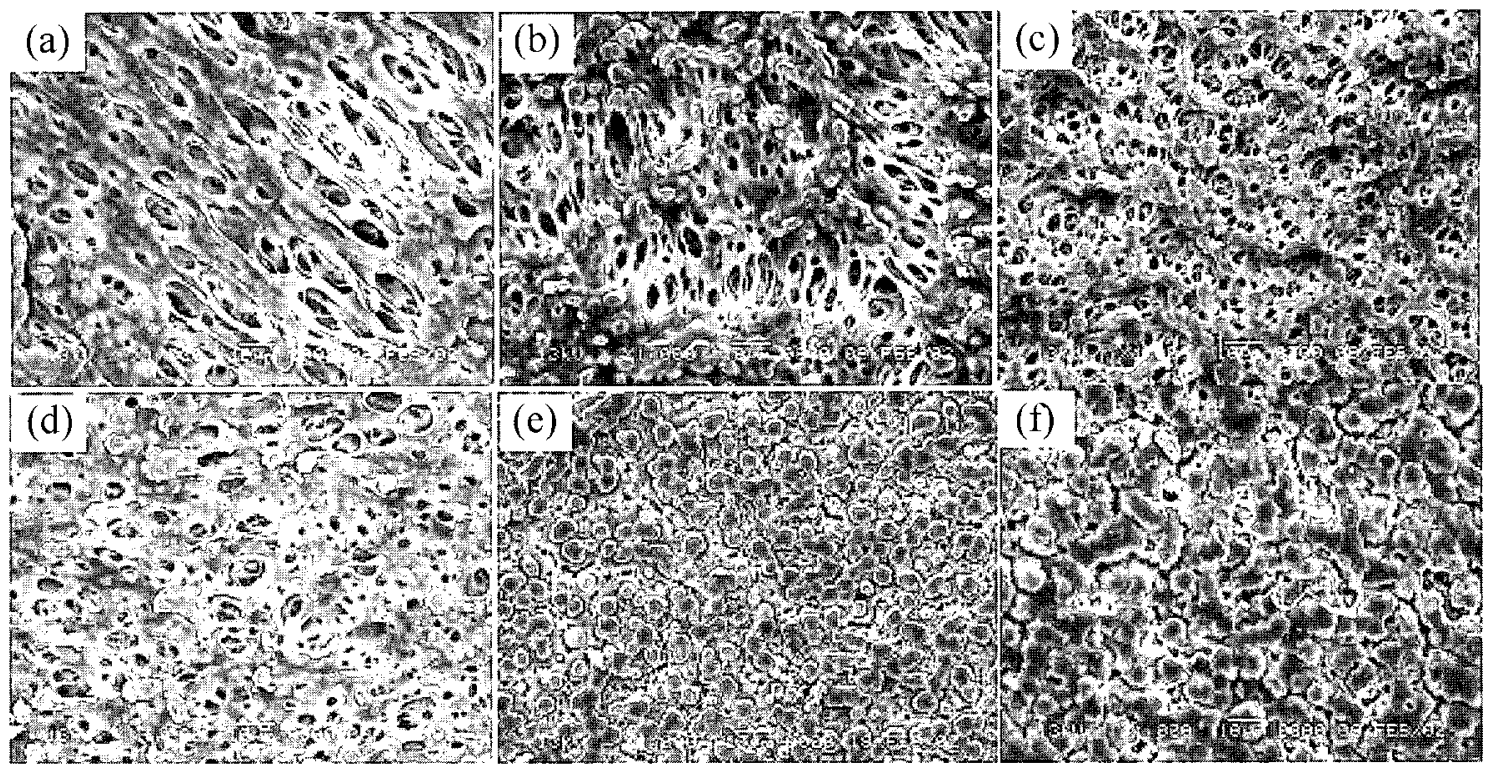

Fig. 1. SEM photographs of surface structure of microporous membranes : NMP extraction a) with deionized water, b) with $20 \mathrm{wt} \%$ methanol, c) with $40 \mathrm{wt} \%$ methanol, d) with $60 \mathrm{wt} \%$ methanol, e) with $80 \mathrm{wt} \%$ methanol, and f) with pure methanol.

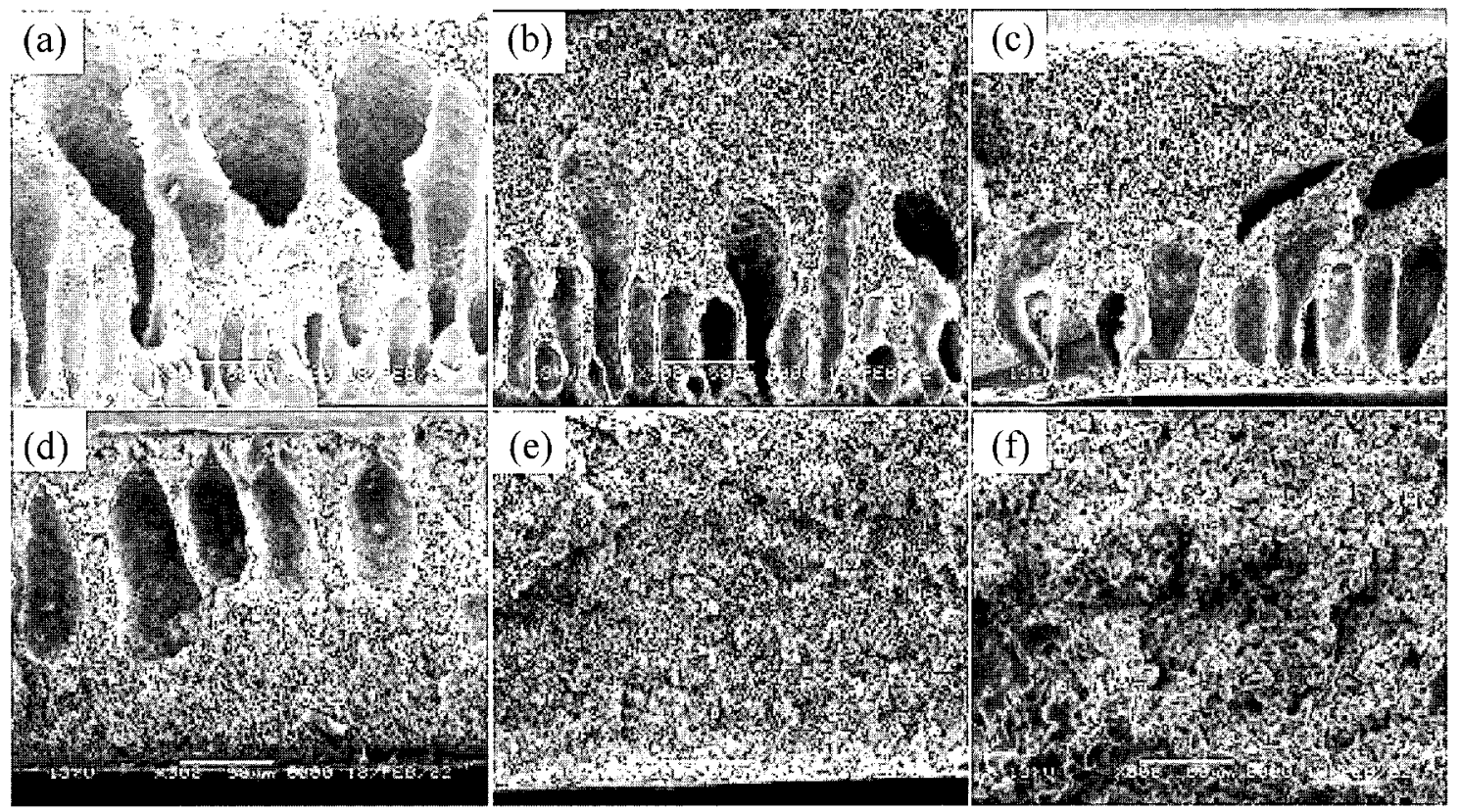

Fig. 2. SEM photographs of bulk structure of microporous membranes : NMP extraction a) with deionized water, b) with 20 wt $\%$ methanol, c) with $40 \mathrm{wt} \%$ methanol, d) with $60 \mathrm{wt} \%$ methanol, e) with $80 \mathrm{wt} \%$ methanol, and f) with pure methanol.

할수록 동굴형태의 큰 기공이 줄어들고 $80 \%$ 메탄올을 사용한 경우 NMP를 추출한 고분자 필름은 동굴형태의 큰 기공없이 전 체적으로 균일한 작은 기공들이 발달되어 있는 것을 관찰할 수 있다. 순수 메탄올을 사용한 경우 고분자 필름은 표면에서 관찰 되어진 것처럼 $\mathrm{P}(\mathrm{VdF}-\mathrm{HFP})$ 가 큰 크기의 클러스터를 형성하였 으며 그 사이에 기공이 불균일하게 형성되었다. 비용매로 증류 수를 사용할 경우에 증류수가 $\mathrm{P}(\mathrm{VdF}-\mathrm{HFP})$ 와 친화력이 없기 때 문에 증류수로 NMP를 추출할 때 NMP가 빠져나오면서 $\mathrm{P}(\mathrm{VdF}-\mathrm{HFP})$ 가 부분적으로 빠르게 침전되어 서로 뭉쳐 큰 기공 을 형성한다. 메탄올 역시 $\mathrm{P}(\mathrm{VdF}-\mathrm{HFP})$ 와 친화력이 없지만 증
류수보다는 크기 때문에 메탄올의 비율이 많은 $80 \%$ 메탄올로 NMP를 추출할 때 NMP가 서서히 빠져나오면서 전체적으로 균 일하게 고분자가 침전되어 $2 \sim 3 \mu \mathrm{m}$ 크기의 균일한 기공이 형성 된다고 사료된다. 그러나 순수 메탄올을 사용하여 NMP를 추출 할 때는 $\mathrm{P}(\mathrm{VdF}-\mathrm{HFP})$ 와 친화력이 증류수 또는 혼합액 보다 크 기 때문에 $\mathrm{P}(\mathrm{VdF}-\mathrm{HFP})$ 의 침전 속도가 너무 느려 전체적으로 큰 클러스터가 형성된다. 이러한 결과로서, 미세기공 고분자 필 름의 제조시 NMP를 추출할 때 사용하는 증류수와 메탄올의 농 도를 조절함으로서 필름내에 만들어지는 기공의 형태와 크기를 제어할 수 있다는 것을 확인하였다. 
Fig. 3은 TEGDME/EC (v/v, 1/1) 용액에 $1 \mathrm{M} \mathrm{LiCF} \mathrm{SO}_{3}$ 를 혼합한 액체 전해질에 미세기공 고분자 필름을 함침시켜 제조 한 고분자 전해질의 저장 시간에 따른 이온 전도도의 변화를 측정한 결과를 나타넨 것이다. 내부구조가 서로 다른 증류수, $40 \%$ 메탄올 및 $80 \%$ 메탄올로 $\mathrm{NMP}$ 를 추출하여 제조한 3 종류 의 고분자 필름을 사용하였다. 증류수로 $\mathrm{NMP}$ 를 추출한 미세기 공 고분자 필름으로 제조한 전해질은 시간이 지날수록 이온전 도도의 감소가 가장 컸으며, $80 \%$ 메탄올로 $\mathrm{NMP}$ 를 추출한 고. 분자 필름으로 제조한 전해질은 저장시간이 증가하여도 이온전 도도는 거의 변화하지 않았다. 이러한 걸과는 SEM을 통해서 관 찰된 고분자 필름들의 내부 기공 구조에서 보듯이 증류수로 $\mathrm{NMP}$ 를 추출한 고분자 필름이 $50 \mu \mathrm{m}$ 이상인 동굴형태의 기공 이 많이 형성되어 있기 때문에 액체 전해질을 함침시켰을 경우 저장 시간이 증가함에 따라 기공 밖으로 액체 전해질이 많이 새어나와 이온 전도도가 감소함을 알 수 있다. 순수 메탄올로 $\mathrm{NMP}$ 를 추출한 필름은 고분자가 클러스터로 뭉쳐있는 구조를 가져서 액체 전해질에 함침 시켰을 때 함침량이 작아 전해질로 서 사용할 수 없었다. $80 \%$ 메탄올로 NMP를 추출한 고분자 필

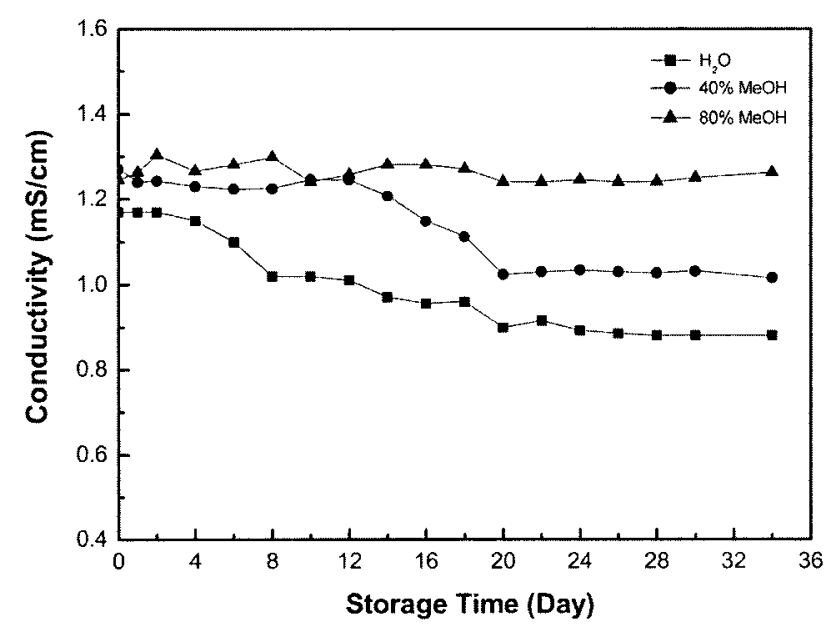

Fig. 3. Ionic conductivity of PVdF based polymer electrolytes as a function of storage time.

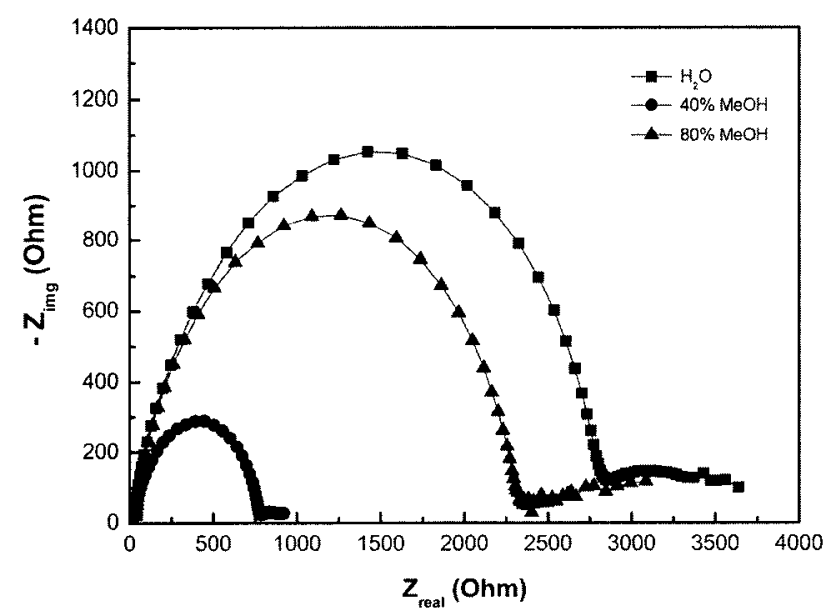

Fig. 4. Nyquist plots of Li/polymer electrolyte/Li cells for interfacial resistance between $\mathrm{Li}$ and polymer electrolyte.
룸은 $2 \sim 3 \mu \mathrm{m}$ 의 간일한 기공이 형성되어 함침된 액체 전해질의 누액이 거의 없으므로 이온 전도도의 변화가 거의 없어 $80 \%$ 메탄올을 사용할 경우 가장 안정적인 이온 전도도를 갖는 고분 자 전해질을 제조할 수 있다는 것을 확인하였다.

Fig. 4는 $1 \mathrm{M} \mathrm{LiCF}_{3} \mathrm{SO}_{3}$-TEGDME/EC (v/v, 1/1)의 액체 전 해질을 미세기공 고분자 필름에 각각 함침시켜 제조한 고분자 전해질과 리틈 전극을 사용하여 구성한 cell의 임피던스 측정 결 과를 나타낸 것이다. $80 \%$ 메탄올로 제조된 미세기공 고분자 전 해질은 리튬 전극과의 계면저항이 $780 \Omega$ 로 계면저항이 가장 적 은 수치를 나타내었고, 증류수를 사용하여 $\mathrm{NMP}$ 를 추출한 미세 기공 고분자 전해질은 $2800 \Omega$ 의 가장 높은 수치의 계면저항을 나타냈다. 이것은 미세기공 고분자 전해질 필름의 제조시 증류 수로 $\mathrm{NMP}$ 를 추출할 때 NMP가 빠져나온 자리에 증류수가 채 워지는데 증류수와 P(VdF-HFP)는 친화력이 없기 때문에 빠르 게 큰 기공이 형성되어 표면이 거칠게 제조된다. 그러나, 메탄 올은 $\mathrm{P}(\mathrm{VdF}-\mathrm{HFP})$ 와 친화력이 증류수 보다 높아 서서히 필름이 형성되어지기 때문에 증류수와 메탄올의 혼합시 메탄올의 함량 이 높은 용액일수록 표면이 매끈한 고분자 필름을 제조하기 용 이하다. 따라서 증류수로 제조된 미세기공 고분자 전해질의 계 면저항이 크게 나타났으며 $80 \%$ 메탄올로 제조한 미세기공 고 분자 전해질이 가장 낮은 것으로 판단된다. 미세기공 고분자 전 해질의 저장시간에 따른 이온 전도도와 측정된 계면저항 톡성 에서 알 수 있듯이 $80 \%$ 메탄올로 제조한 고분자 필름은 균일 한 미세기공이 분포하는 고분자 전해질로 가장 우수한 특성을 나타내었다.

$80 \%$ 메탄올로 제조한 $\mathrm{P}(\mathrm{VdF}-\mathrm{HFP})$ 의 미세기공 고분자 필름 에 $\mathrm{LiCF}_{3} \mathrm{SO}_{3}$-TEGDME/EC $(\mathrm{v} / \mathrm{v}, 1 / 1)$ 의 액체 전해질을 함침시 켜 제조한 고분자 전해질을 $5^{\circ} \mathrm{C} / \mathrm{min}$ 의 가열속도로 $\mathrm{DSC}$ 를 측정 한 결과롤 Fig. 5에 나타냈다. $\mathrm{P}(\mathrm{VdF}-\mathrm{HFP})$ 고분자 필름은 $140^{\circ} \mathrm{C}$ 근처에서 흡열피크가 나타났다. 일반적으로 $\mathrm{P}(\mathrm{VdF}-\mathrm{HFP})$ 의 경우 $140^{\circ} \mathrm{C}$ 이상에서 용응온도를 가진다. 액체 전해질을 함 침시킨 고분자 전해질은 $100^{\circ} \mathrm{C}$ 근처에서 흡열피크가 나타났는 데 이것은 액체 전해질에 미세기공 고분자 필름이 팽윤되어 $\mathrm{P}(\mathrm{VdF}-\mathrm{HFP})$ 의 결정성이 줄어들었기 때문으로 판단된다.

Fig. 6은 $80 \%$ 메탄올로 제조한 $\mathrm{P}(\mathrm{VdF}-\mathrm{HFP})$ 의 미세기공 고 분자 필름에 $1 \mathrm{M} \mathrm{LiCF} \mathrm{SO}_{3}-\mathrm{TEGDME} / \mathrm{EC}(\mathrm{v} / \mathrm{v}, 1 / 1)$ 의 액체

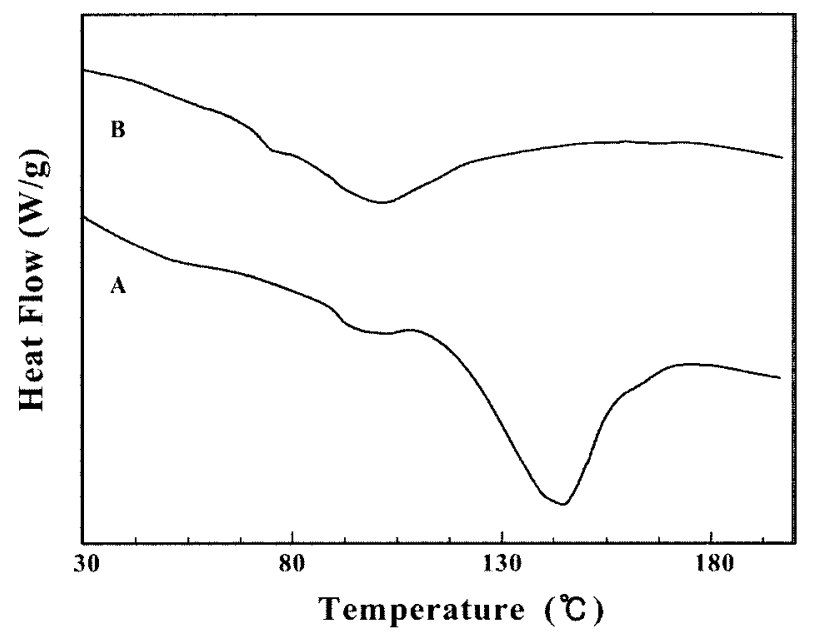

Fig. 5. DSC curves of microporous film and polymer electrolyte(A: PVdF, B: PVdF + $\mathrm{LiCF}_{3} \mathrm{SO}_{3}$-TEGDME/EC). 


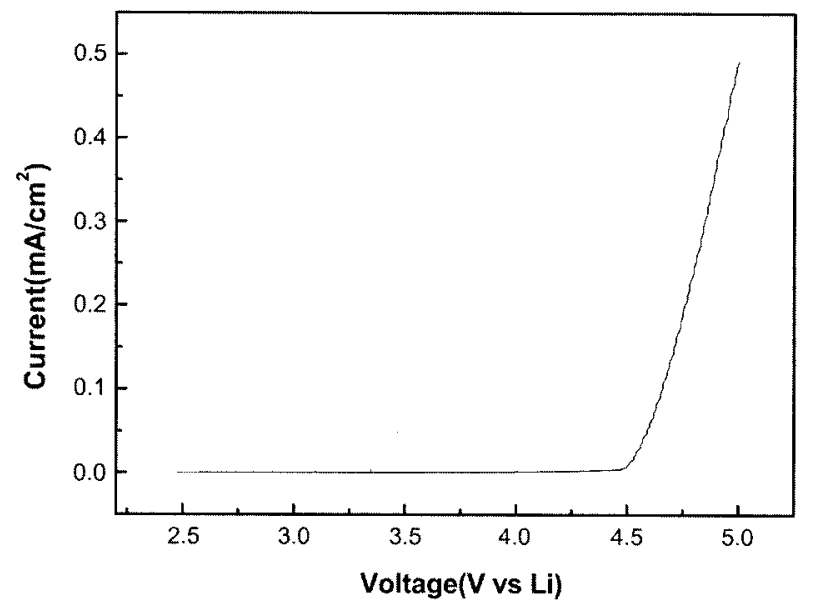

Fig. 6. Linear sweep voltammogram of microporous membrane containing $1 \mathrm{M} \mathrm{LiCF}_{3} \mathrm{SO}_{3}$-TEGDME/EC.

전해질을 함침시켜 제조한 고분자 전해질의 전기화학적 안정성 을 알아보기 위해 $0.1 \mathrm{mV} / \mathrm{sec}$ 의 주사속도로 $\mathrm{LSV}$ 를 측정한 결 과이다. 그림에서 보듯이 $4.5 \mathrm{~V}$ 까지 거의 전류가 흐르지 않으며 안정한 상태를 유지하다가 $4.5 \mathrm{~V}$ 이상에서 전류가 급증하는 현 상을 나타내어 고분자 전해질의 전기화학적 산화가 $4.5 \mathrm{~V}$ 이상 에서 일어나는 것을 알 수 있다. 이러한 결과로서 $80 \%$ 메탄올 로 제조한 미세기공 고분자 필름을 사용한 고분자 전해질이 $1.7 \sim 3.0 \mathrm{~V}$ 에서 사용되는 리틈 설퍼전지 뿐만아니라 $4 \mathrm{~V}$ 급의 고 전압용 리튬 이은전지에 사용 가능함을 확인하였다.

Table 1은 $\mathrm{LiCF}_{3} \mathrm{SO}_{3}$ 를 사용하여 여러 가지 유기용매를 단독 또는 두가지 유기용매를 각각 $1: 1$ 부피비로 혼합하여 액체 전 해질을 제조한 후, $80 \%$ 메탄올로 제조된 미세기공 고분자 필름 에 함침시켜 액체 전해질의 함침량과 상온 이온전도도를 측정 한 결과를 나타낸 것이다. 액체 전해질의 함침율은 식 (1)에 의 해 계산하였다.

$$
\text { uptake }(\%)=\frac{W-W_{o}}{W} \times 100
$$

$W_{o}$ 는 미세기공 고분자 필름의 질량을 나타내며, $W$ 는 액체 전 해질을 함침시킨 고분자 전해질의 질량이다. 그러므로 함침량은 액체 전해질을 포함하는 고분자 전해질에서 액체 전해질의 함 량을 나타낸다. 액체 전해질의 함침율은 $70 ~ 77 \%$ 정도로 거의 유사 하였고 TEGDME, PC 등과 같이 단일 유기용매를 사용 하는 것 보다 두 유기용매를 혼합하여 사용하는 것이 이온 전

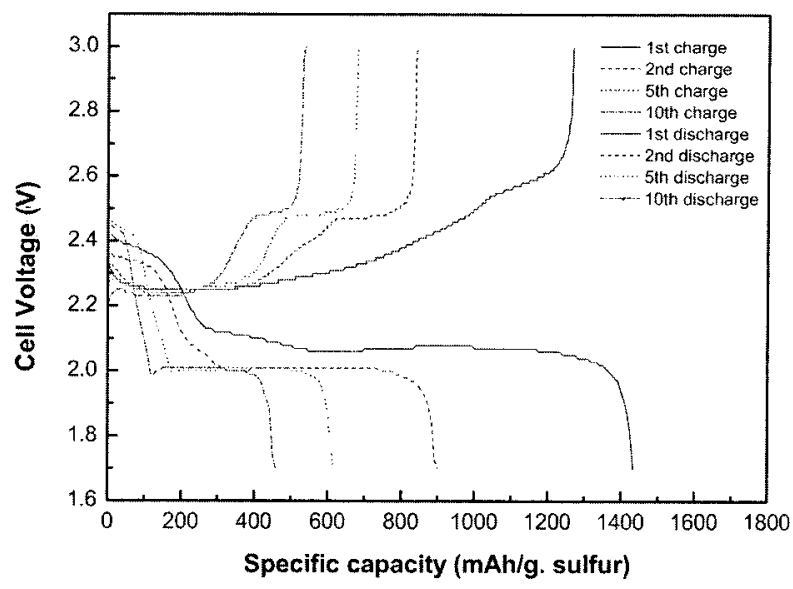

Fig. 7. Specific capacity of $\mathrm{Li} / \mathrm{S}$ cell with cycling.

도도갸 높게 나태났다. 전반적으로 이온전도도가 리튬 전지용 고분자 전해질로 사용 가능한 $10^{-3} \mathrm{~S} / \mathrm{cm}$ 이상 나타났으며, TEGDME/PC (v/v, 1/1)를 사용한 경우 $2 \times 10^{-3} \mathrm{~S} / \mathrm{cm}$ 로 가장 높 게 나타났다.

Table 2 는 $80 \%$ 메탄올을 사용하여 만든 미세기공 고분자 필 름에 유기용매로 TEGDME/EC(v/v, 1/1)를 사용하여 여러 종류 의 리튬염을 첨가하여 제조한 액체 전해질을 함침시켜 각각의 이온전도도를 나타낸 것이다. 이온전도도는 리튬염에 따라 $\mathrm{LiPF}_{6}>\mathrm{LiBF}_{4}>\mathrm{LiCF}_{3} \mathrm{SO}_{3}$ 순으로 높게 나타났으며, $\mathrm{LiPF}_{6}$ 를 사용하였을 경우 상온 이온전도도는 $3.3 \times 10^{-3} \mathrm{~S} / \mathrm{cm}$ 로 높게 나 타났다.

Fig. 7은 미세기공 고분자 전해질을 사용한 Li/sulfuir cell의 충 - 방전곡선을 나타낸 것이다. 리튬 설퍼 전지의 전형적인 $2.4 \mathrm{~V}$ 와 $2.1 \mathrm{~V}$ 에서 평탄구간이 냐오고 초기 방전용랑이 1450 $\mathrm{mAh} / \mathrm{g}$ 으로 높게 나타났다. 두번째 방전부터 급격한 용량 감소 를 보이는데 이것은 방전시 sulfur갸 폴리설파이드로 변해 최종 적으로 $\mathrm{Li}_{2} \mathrm{~S}$ 가 되어지고 충전시 다시 $\mathrm{Li}_{2} \mathrm{~S}$ 가 폴리설파이느로 되 어 sulfur로 전환되는 반응이 잘 일어나지 않은 것으로 판단된 다. ${ }^{21)}$ 충전시 sulfur 전극에서 산화가 일어나면서 폴리설파이드 가 고분자 전해질에 용해되어 폴리설파이드가 전해칠내에서 리 튠표면으로 확산되고 리튬표면에서 환원반응이 동시에 일어나 는 셔틀메카니즘 반응에 기인하여 용량감소가 일어난다. 향후 리튬 설퍼 전지의 최적화가 이루어지년 미세기공 고분자 전해 질이 리틈 이차전지용 고분자 전해질료 우수한 특성을 나타낼 것으로 판단된다.

Table 1. Ionic conductivity of polymer electrolytes containing $1 \mathrm{M} \mathrm{LiCF}_{3} \mathrm{SO}_{3}$ in different organic electrolytes at room temperature.

\begin{tabular}{lcccccccc}
\hline \multirow{2}{*}{ Liquid electrolyte } & \multirow{2}{*}{ TEGDME } & PC & TEGDME /PC & $\begin{array}{c}\text { TEGDME/ } \\
\text { DMC }\end{array}$ & TEGDME/EC & PC/DMC & PC/EC & DMC/EC \\
\hline uptake $(\%)$ & 73 & 70 & 73 & 77 & 70 & 70 & 74 \\
Ionic conductivity $(\mathrm{mS} / \mathrm{cm})$ & 0.88 & 0.79 & 2 & 1.6 & 1.9 & 1.6 & 1.4 \\
\hline
\end{tabular}

Table 2. Ionic conductivity of polymer electrolytes containing different lithium salts in TEGDME/EC at room temperature.

\begin{tabular}{cccc}
\hline Polymer electrolyte & $\mathrm{LiCF}_{3} \mathrm{SO}_{3}$-TEGDME/EC & $\mathrm{LiBF}_{4}$-TEGDME/EC & $\mathrm{LiPF}_{6}-\mathrm{TEGDME} / \mathrm{EC}$ \\
\hline Ionic conductivity $(\mathrm{mS} / \mathrm{cm})$ & 1.9 & 2.8 & 3.3 \\
\hline
\end{tabular}




\section{4. 결 론}

고분자 매트릭스로 $\mathrm{P}(\mathrm{VdF}-\mathrm{HFP})$ 와 용매로 NMP를 사용하여, 고분자 필름의 기공을 형성시키기 위해 NMP를 추출하는 비용 매로 증류수, 증류수-메탄올 혼합물, 메탄올을 사용하는 상전이 법을 이용하여 제조한 고분자 전해질의 전기화학적 특성을 측 정한 결과 아래와 같은 결론을 얻었다.

1. 미세기공 고분자 필름의 제조시, NMP 추출에 사용되는 증 류수와 메탄올의 혼합 농도를 조절함으로써 고분자 필름 내 부의 기공 구조 형성을 제어할 수 있었다.

2. $80 \%$ 메탄올로 제조한 미세기공 고분자 필름에 $1 \mathrm{M}$ $\mathrm{LiCF}_{3} \mathrm{SO}_{3}$-TEGDME/EC의 액체 전해질을 함침시켜 제조한 고분자 전해질이 상온 이온전도도가 가장 녿았으며, 저장 시 간에 따른 이온전도도 감소도 적었다. 또한 리틈 전극과의 계면저항도 가장 낮게 나타났다.

3. 미세기공 고분자 필름을 여러 종류의 유기용매를 사용하여 제조한 고분자 전해질의 이온전도도를 측정한 결과 상업적으 로 사용 가능한 $10^{-3} \mathrm{~S} / \mathrm{cm}$ 이상의 이온전도도를 나타내었으 며, $1 \mathrm{M} \mathrm{LiCF} \mathrm{SO}_{3}$-TEGDME/PC의 경우 $2 \times 10^{-3} \mathrm{~S} / \mathrm{cm}$ 의 이 온전도도를 보였다.

4. 리툮염에 따른 이온전도도를 측정한 결과 이온전도도가 $\mathrm{LiPF}_{6}>\mathrm{LiBF}_{4}>\mathrm{LiCF}_{3} \mathrm{SO}_{3}$ 순으로 나타났으며, $\mathrm{LiPF}_{6}$ 를 사 용한 고분자 전해질이 상온에서 $3.3 \times 10^{-3} \mathrm{~S} / \mathrm{cm}$ 로 나타났다. 이러한 결과로서 상전이법을 사용하여 제조한 미세기공 고분 자 펄름을 사용한 고분자 전해질이 리튬 이차전지용 전해질 로 사용 가능함을 확인하였다.

\section{감사의 글}

본 연구는 대학 IT연구센터 육성-지원사업의 연구결과로 수 행되었으며, 이에 감사드립니다.

\section{참고문헌}

1. D. E. Fenton, J. M. Parker, and P. V. Wright, Polymer, 14, 589 (1973).
2. M. Watanabe, T. Endo, A. Nishimoto, K. Miura, and M. Yanagida, J. Power Sources, 81/82, 786 (1999).

3. A. S. Best, A. Ferry, D. R. MacFarlane, and M. Forsyth, Solid State Ionics, 126, 269 (1999).

4. G. B. Appetechi, F. Croce, and B. Scrosati, J. Power Sources, 66, 77 (1997).

5. M. Watanabe, M. Kanba, K. Nagaoka, and I. Shinohara, J. Appl. Electrochem., 27, 4191 (1982).

6. K. M. Abraham and M. Alamgir, J. Electrochem. Soc., 137, 1657 (1990).

7. O. Bohnke, C. Rousselot, P.A. Gillet, and C. Truche, J. Electrochem. Soc., 139, 1862 (1992).

8. E. Tsuchida, H. Ohno, and K. Tsunemi, Electrochim. Acta, 28, 591 (1983).

9. H. S. Choe, J. Giaccai, M. Alamgir, and K.M. Abraham, Electrochim. Acta, 40, 2289 (1995).

10. D. W. Kim, Y. R. Kim, J. K. Park, and S. I. Moon, Solid State Ionics, 106, 329 (1998).

11. J. Y. Song, Y. Y. Wang, and C. C. Wan, J. Power Sources, 77, 183 (1999).

12. J. M. Tarascon, A. S. Goztz, C. Schmutz, F. Shokoohi, and P. C. Warren, Solid State Ionics, 86, 49 (1996).

13. Z. Jiang, B. Carroll, and K. M. Abraham, Electrochim. Acta, 42, 2667 (1997).

14. Y. Saito, C. Capiglia, H. Kataoka, H. Yamamoto, H. Ishikawa, and P. Mustarelli, Solid State Ionics, 136/137, 1161 (2000).

15. P. Periasamy, K. Tatsumi, M. Shikano, T. Fujieda, Y. Saito, T. Sakai, M. Mizuhata, A. Kajinami, and S. Deki, J. Power Sources, 88, 269 (2000).

16. J. M. Tarascon, A. S. Gozdz, C. Schmutz, F. Shokoohi, and P. C. Warren, Solid State Ionics, 86-88, 49 (1996).

17. F. Boudin, X. Andrieu, C. Jehoulet, and I. I. Olsen, J. Power Sources, 81/82, 804 (1999).

18. A. Du Pasquier, P. C. Warren, D. Culver, A. S. Gozdz, G. G. Amatucci, and J. M. Tarascon, Solid State Ionics, 135, 249 (2000).

19. T. Michot, A. Nishimoto, and M. Watanabe, Electrochim. Acta, 45, $1347(2000)$.

20. D. W. Kim and Y. K. Sun, J. Power Sources, 102, 41 (2001).

21. H. S. Ryu, C. W. Park, K. W. Kim, J. H. Ahn, J. Y. Lee, and H. J. Ahn, Proceedings of the 43rd Battery Symposium in Japan, 62 (2002). 